\title{
The Influence of Product Mix, Promotion Mix and Brand Image on Consumer Purchasing Decisions of Sari Roti Products in South Tangerang
}

\author{
Jasmani, Denok Sunarsi \\ Universitas Pamulang \\ E-mail: dosen01770@unpam.ac.id
}

(Received: December-2019; Reviewed: January-2020; Accepted: February-2020;

Avalaibel Online: February-2020; Published: March-2020)

\begin{abstract}
Along with the many types of bread that appear now, one of which is white bread. Companies are required to make bread products that can meet the wishes of the community. This study aims to determine the effect of product mix, promotion mix and brand image on consumer purchasing decisions of Sari Roti products in South Tangerang. The method used was explanatory research with a sample of 96 consumers. The analysis technique uses statistical analysis with regression testing, correlation, determination, and hypothesis testing. The results of this study the product mix significantly influence consumer purchasing decisions by $30.3 \%$, the hypothesis test obtained significance $0,000<0.05$. The promotion mix has a significant effect on consumer purchasing decisions by $41.2 \%$, the hypothesis test obtained significance $0,000<0.05$. Brand image has a significant effect on consumer purchasing decisions by $26.8 \%$, hypothesis testing obtained significance $0,000<0.05$. Product mix, promotion mix, and brand image simultaneously have a significant effect on consumer purchasing decisions by $49.3 \%$, hypothesis testing obtained significance of $0,000<0.05$.
\end{abstract}

Keywords: Product mix, promotion mix, brand image, consumer purchasing decisions

\section{INTRODUCTION}

The concept of marketing emerged in the mid-1950s and opposed many previous concepts. Instead of a product-centered philosophy of making and selling, we shift to a philosophy of understanding and responding (Barat, 2009; Constantinides, 2006). Nowadays, where the level of competition is so tight, the pattern as above has long been abandoned. Many producers before their goods are produced, they first conduct market research in various ways, for example by testing the market through advertising, as if the goods already exist. The aim is none other than to see the current demand conditions for the product to be produced.

Along with the many types of bread that appear now, one of which is white bread. Companies are required to make bread products that can meet the wishes of the community. Because we know that bread is food that can be consumed at any time (morning, noon, or 
night), and can also be consumed by many people, including students. With practical packaging, and durable, often people choose bread as a provision for their activities rather than rice. In addition, the current lifestyle has changed, from rice consumption to bread consumption where community activities are increasingly busy and do not have time for breakfast before doing their daily activities. Various types of white bread offered in the market are Bread Talk, Sari Roti, Lauw, Paparoti, Mr. Bread, Majestik, and Holand Bakery. They compete with each other in terms of taste, packaging, price, even promotions to attract consumers in making purchasing decisions.

Everything can be offered to the market to get attention, be bought, used, or consumed that can satisfy wants or needs (Kotler dan Amstrong, 2008; Peter \& Olson, 2014; Sunyoto, 2014; Wahyuningsih \& Tanamal, 2008). In the development of its business is the achievement of objectives to create and retain customers. In its development, consumers are the key determinants of success or failure in marketing their citizens. Companies must be able to recognize early the needs and expectations of consumers. A marketing manager must have extensive knowledge of consumer behavior in order to be able to take advantage of the slightest opportunity available (Kilgour, 2006; Purba, 2012; Swastha, 2008)

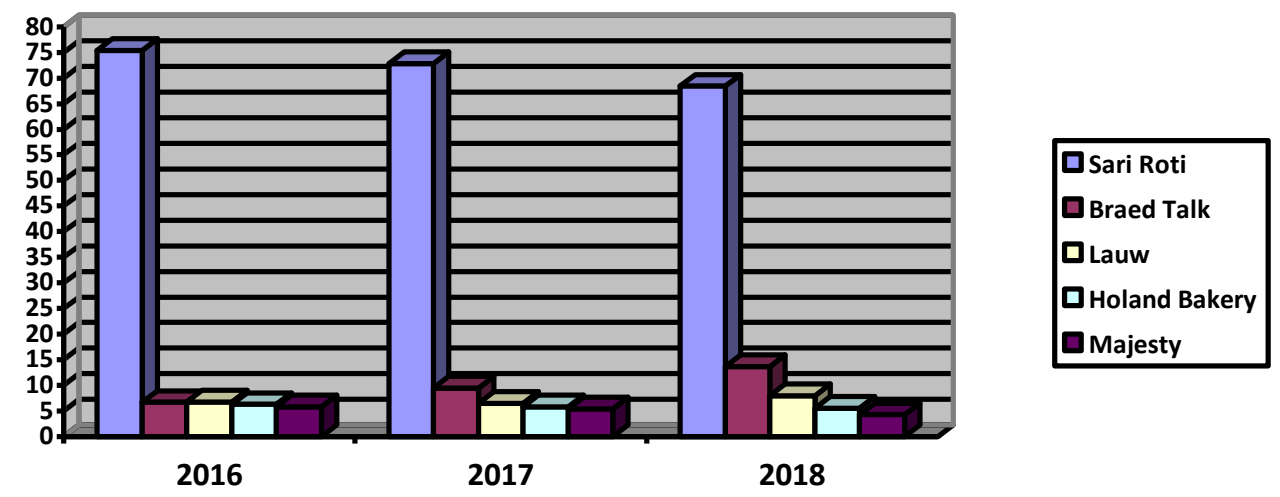

Ficture 1

Top Brand Index of Tawar Bread

Based on the Top Brand Index graphic data, it can be seen that Sari Roti in 2016 is still the market leader with $75.40 \%$ market management, but in 2017 it decreased to $72.80 \%$ and in 2018 it also decreased to $68.40 \%$. This clearly must be a concern of the company given the competition in this industry is very tight and competitive.

In a business, a company needs to think about how to make decisions about the product mix that will be produced now and in the future (Al Badi, 2015; Riaz \& Tanveer, 2012). The product mix is one element that must be considered by a business (Adi \& Soepangkat, 2012; Mayer, Melitz, \& Ottaviano, 2014; Shinta, 2011). With a good product mix, the company can attract consumers to make purchases. According to (Kotler, 2013) the product mix consists of width, length, and depth of a certain consistency.

Promotional mix is an effective promotional activity tool in an effort to increase sales of products and services (Hollensen, 2010; Mayer et al., 2014; Susanti, 2015; Wariki, Mananeke, \& Tawas, 2015). The use of this promotional mix is one of the strategies to build communication carried out by companies with the aim of increasing value and building relationships with consumers. According to (Kotler dan Amstrong, 2008) berpendapat bahwa bauran promosi adalah campuran spesifik dari alat-alat promosi yang used by the company to persuasively communicate customer value and build customer relationships. Building 
communication can be done with forms of advertising promotion. sales promotion, personal selling, public relations, direct marketing.

Brand image has an important role in the development of a brand (Keller, 2001; Mukherjee, 2011; Zhang, 2015). Brand image concerns the reputation of a product as a guide for consumers to try and consume a particular product or service (Fristiana, 2012; Habibah \& Sumiati, 2016; Tingkir, 2014).

Purchasing decisions are greatly influenced by consumer behavior. The purchase decision process is the solution of problems in order to meet the desires or needs of consumers. According to (Alma, 2011), purchasing decisions are decisions that are influenced by financial economics, technology, politics, culture, products, prices, locations, promotions, physical, people and processes so as to form an attitude to consumers to process all information and draw conclusions in the form of responses that appear what products will be bought. In choosing a product, customers will have to consider several factors such as price, product quality, brand, and so on. With a brand, it will be easier for the public to remember a product that will differentiate it from other similar products. Brands in shifting need to be perceived as highquality products so that consumers can understand a product only through function, image, and quality. In general, consumers face difficulties in assessing and understanding the quality of a product rationally and in the true sense (Jasmani, 2018)

\section{METHOD}

The type of research used is associative, where the aim is to find out the relationship between variables. The population in this study amounted to 96 consumers who bought Sari Roti products in South Tangerang. The sampling technique in this study is purpose sampling using the (Purba, 2012) formula, where the number of consumers is not known with certainty. With the use of the formula obtained samples in this study amounted to 96 consumers. In analyzing the data used the instrument test, classical assumption test, regression, coefficient of determination and hypothesis testing.

\section{RESULT AND DISCUSSION}

PT. Nippon Indosari Corpindo (Tbk) is one of the industry players that produces bread. In an effort to maintain product quality, companies must have a high commitment to offering high quality, hygienic and halal products, therefore the Company implements the GMP system (Good Manufacturing Practice), SSOP (Sanitation Standard Operating Procedure), SJH (Sistem Jaminan Halal), ISO 9001: 2008 Standards (Quality Management System), and ISO 22000: 2005 (Food Safety Management System). Sari Roti products have been registered with the Badan Pengawas Obat dan Makanan (BPOM) and have received halal certification from the Majelis Ulama Indonesia (MUI). 


\section{Descriptive Analysis}

This test is used to find out the minimum and maximum scores and the mean score and the standard deviation of each variable. The results are as follows:

Table 1.

Descriptive Statistics Analysis Results

\section{Descriptive Statistics}

\begin{tabular}{ll|l|l|l|l}
\hline & $\mathrm{N}$ & Minimum & Maximum & Mean & Std. Deviation \\
\hline Product Mix (X1) & 96 & 28 & 46 & 38.05 & 3.737 \\
\hline Promotion Mix (X2) & 96 & 31 & 46 & 37.80 & 3.849 \\
\hline Brand Image (X3) & 96 & 31 & 48 & 38.04 & 3.656 \\
\hline Purchase Decision (Y) & 96 & 30 & 47 & 38.57 & 3.565 \\
\hline Valid N (listwise) & 96 & & & & \\
\hline
\end{tabular}

The product mix obtained a minimum variance of 28 and a maximum variance of 46 with a mean score of 3.80 with good criteria with a standard deviation of 3.737 . Promotion mix obtained a minimum variance of 31 and a maximum variance of 46 with a mean score of 3.78 with good criteria with a standard deviation of 3.849. The brand image obtained a minimum variance of 31 and a maximum variance of 48 with a mean score of 3.80 with good criteria with a standard deviation of 3.656. Consumer purchasing decisions obtained a minimum variance of 30 and a maximum variance of 47 with a mean score of 3.86 with good criteria with a standard deviation value of 3.565 .

\section{Regression Multiple Analysis}

This regression test is intended to determine changes in the dependent variable if the independent variable changes. The test results are as follows:

Table 2

Multiple Linear Regression Testing Results

\section{Coefficients $^{\mathrm{a}}$}

\begin{tabular}{|c|c|c|c|c|c|c|}
\hline & \multirow[b]{2}{*}{ Model } & \multicolumn{2}{|c|}{$\begin{array}{l}\text { Unstandardized } \\
\text { Coefficients }\end{array}$} & \multirow{2}{*}{$\begin{array}{c}\text { Standardized } \\
\text { Coefficients } \\
\text { Beta }\end{array}$} & \multirow[b]{2}{*}{$\mathrm{t}$} & \multirow[b]{2}{*}{ Sig. } \\
\hline & & B & Std. Error & & & \\
\hline \multirow[t]{4}{*}{1} & (Constant) & 8.306 & 3.311 & & 2.508 & .014 \\
\hline & Product Mix (X1) & .211 & .089 & .221 & 2.363 & .020 \\
\hline & Promotion Mix (X2) & .369 & .091 & .398 & 4.043 & .000 \\
\hline & Brand Image (X3) & .218 & .085 & .224 & 2.565 & .012 \\
\hline
\end{tabular}

a. Dependent Variable: Purchase Decision (Y)

Based on the test results in the above table, the regression equation $\mathrm{Y}=8,306+0,211 \mathrm{X} 1+$ $0,369 \mathrm{X} 2+0,218 \mathrm{X} 3$ is obtained. A constant of 8.306 means that if there is no product mix, promotion mix, and brand image, then there is a value of a consumer purchasing decision of 8.306 points. The regression coefficient of the product mix variable is 0.211 , this number is positive, meaning that every time there is an increase in the product mix of 0.211 points, the consumer purchasing decision will also increase by 0.211 points. The regression coefficient of the promotion mix variable is 0.369 , this number is positive, meaning that every time there is an increase in the promotion mix by 0.369 points, the consumer purchasing decision will also increase by 0.369 points. The regression coefficient of the brand image variable is 0.218 , this 
number is positive, meaning that every time there is an increase in the brand image by 0.218 points, the consumer purchasing decision will also increase by 0.218 points.

\section{Correlation Coefficient Analysis}

Correlation coefficient analysis is intended to determine the level of strength of the relationship of the independent variable on the dependent variable both partially and simultaneously. The test results are as follows:

Table 3.

Test Results Correlation Coefficient of Product Mix on Consumer Purchasing Decisions.

\section{Correlations $^{\mathrm{b}}$}

\begin{tabular}{lll|l}
\hline & & \multicolumn{1}{c}{$\begin{array}{c}\text { Product Mix } \\
(\mathrm{X} 1)\end{array}$} & \multicolumn{1}{c}{$\begin{array}{c}\text { Purchase } \\
\text { Decision (Y) }\end{array}$} \\
\hline Product Mix (X1) & Pearson Correlation & 1 & $.551^{* *}$ \\
\cline { 2 - 4 } & Sig. (2-tailed) & & .000 \\
\hline Purchase Decision (Y) & Pearson Correlation & $.551^{* *}$ & 1 \\
\cline { 2 - 4 } & Sig. (2-tailed) & .000 & \\
\hline
\end{tabular}

**. Correlation is significant at the 0.01 level (2-tailed).

b. Listwise $\mathrm{N}=96$

Based on the test results obtained by a correlation value of 0.551 means that the product mix has a moderate relationship to consumer purchasing decisions.

Table 4.

Test Results Correlation Coefficient Promotion Mix Against Consumer Purchasing Decisions.

Correlations $^{\mathbf{b}}$

\begin{tabular}{lll|l}
\hline & & $\begin{array}{c}\text { Promotion Mix } \\
(\mathrm{X} 2)\end{array}$ & \multicolumn{1}{c}{$\begin{array}{c}\text { Purchase } \\
\text { Decision (Y) }\end{array}$} \\
\hline Promotion Mix (X2) & Pearson Correlation & 1 & $.642^{* *}$ \\
\cline { 2 - 4 } & Sig. (2-tailed) & & .000 \\
\hline Purchase Decision (Y) & Pearson Correlation & $.642^{* *}$ & 1 \\
\cline { 2 - 4 } & Sig. (2-tailed) & .000 & \\
\hline
\end{tabular}

**. Correlation is significant at the 0.01 level (2-tailed).

b. Listwise $\mathrm{N}=96$

Based on the test results obtained a correlation value of 0.642 means that the promotional mix has a strong relationship with consumer purchasing decisions. 
Table 5.

Correlation Coefficient Test Results For Brand Image to Consumer Purchasing Decisions.

\section{Correlations $^{\mathrm{b}}$}

\begin{tabular}{lll|l} 
& \multicolumn{1}{c}{$\begin{array}{c}\text { Brand Image } \\
(\mathrm{X} 3)\end{array}$} & \multicolumn{1}{c}{$\begin{array}{c}\text { Purchase } \\
\text { Decision (Y) }\end{array}$} \\
\hline Brand Image (X3) & Pearson Correlation & 1 & $.517^{* *}$ \\
\cline { 2 - 4 } & Sig. (2-tailed) & & .000 \\
\hline Purchase Decision (Y) & Pearson Correlation & $.517^{* *}$ & 1 \\
\cline { 2 - 4 } & Sig. (2-tailed) & .000 & \\
\hline \multirow{2}{*}{$\begin{array}{l}\text { **. Correlation is significant at the 0.01 level (2-tailed). } \\
\text { b. Listwise N=96 }\end{array}$} & &
\end{tabular}

Based on the test results obtained a correlation value of 0.517 means that brand image has a strong relationship with consumer purchasing decisions.

Table 6 .

Test Results Correlation Coefficient of Product Mix, Promotion Mix, and Brand Image Simultaneously on Consumer Purchasing Decisions.

\section{Model Summary}

\begin{tabular}{|c|c|c|c|c|}
\hline Model & $\mathrm{R}$ & R Square & $\begin{array}{c}\text { Adjusted R } \\
\text { Square }\end{array}$ & Std. Error of the Estimate \\
\hline 1 & $.702^{\mathrm{a}}$ & 493 & .477 & 2.579 \\
\hline
\end{tabular}

a. Predictors: (Constant), Brand Image (X3), Product Mix (X1), Promotion Mix (X2)

Based on the test results obtained by the correlation value of 0.702 means that the product mix, promotional mix, and brand image simultaneously have a strong relationship with consumer purchasing decisions.

\section{Analysis of the Coefficient of Determination}

Analysis of the coefficient of determination is intended to determine the percentage of influence of the independent variable on the dependent variable either partially or simultaneously. The test results are as follows:

Table 7.

Test Results for the Product Mix Determination Coefficient on Consumer Purchasing Decisions. Model Summary

\begin{tabular}{|c|c|c|c|c|}
\hline Model & $\mathrm{R}$ & R Square & $\begin{array}{l}\text { Adjusted R } \\
\text { Square }\end{array}$ & $\begin{array}{l}\text { Std. Error of the } \\
\text { Estimate }\end{array}$ \\
\hline 1 & $.551^{\mathrm{a}}$ & .303 & .296 & 2.991 \\
\hline
\end{tabular}

a. Predictors: (Constant), Product Mix (X1),

Based on the test results obtained a determination value of 0.303 means that the product mix has an influence contribution of $30.3 \%$ on consumer purchasing decisions. 
Table 8 .

Test Results for the Promotion Mix Determination Coefficient on Consumer Purchasing Decisions.

\section{Model Summary}

\begin{tabular}{|c|c|c|c|c|}
\hline Model & $\mathrm{R}$ & R Square & $\begin{array}{l}\text { Adjusted R } \\
\text { Square }\end{array}$ & $\begin{array}{l}\text { Std. Error of the } \\
\text { Estimate }\end{array}$ \\
\hline 1 & $.642^{\mathrm{a}}$ & .412 & .406 & 2.748 \\
\hline
\end{tabular}

a. Predictors: (Constant), Promotion Mix (X2)

Based on the test results obtained a determination value of 0.412 means that the promotional mix has an influence contribution of $41.2 \%$ on consumer purchasing decisions.

Table 9.

Test Results for the Brand Image Determination Coefficient on Consumer Purchasing Decisions.

\section{Model Summary}

\begin{tabular}{|c|c|c|c|c|}
\hline Model & $\mathrm{R}$ & R Square & $\begin{array}{l}\text { Adjusted R } \\
\text { Square }\end{array}$ & $\begin{array}{l}\text { Std. Error of the } \\
\text { Estimate }\end{array}$ \\
\hline 1 & $.517^{\mathrm{a}}$ & .268 & .260 & 3.067 \\
\hline
\end{tabular}

a. Predictors: (Constant), Brand Image (X3)

Based on the test results obtained a determination value of 0.268 means that the brand image has an influence contribution of $26.8 \%$ on consumer purchasing decisions.

Table 10.

Test Results for the Determination Coefficient of the Product Mix, Promotion Mix and Brand Image on Consumer Purchasing Decisions.

Model Summary

\begin{tabular}{|c|c|c|c|c|}
\hline Model & $\mathrm{R}$ & R Square & Adjusted R Square & $\begin{array}{c}\text { Std. Error of the } \\
\text { Estimate }\end{array}$ \\
\hline 1 & $.702^{\mathrm{a}}$ & .493 & .477 & 2.579 \\
\hline
\end{tabular}

a. Predictors: (Constant), Brand Image (X3), Product Mix (X1), Promotion Mix (X2)

Based on the test results obtained a determination value of 0.493 means that the product mix, promotional mix, and brand image simultaneously have an influence contribution of $49.3 \%$ to consumer purchasing decisions, while the remaining $50.7 \%$ is influenced by other factors. 


\section{Hypotesis Testing}

Hypothesis testing with a t-test is used to find out which partial hypotheses are accepted.

Table 11.

Hypothesis Test Results Product Mix Against Consumer Purchasing Decisions.

\section{Coefficients $^{\mathrm{a}}$}

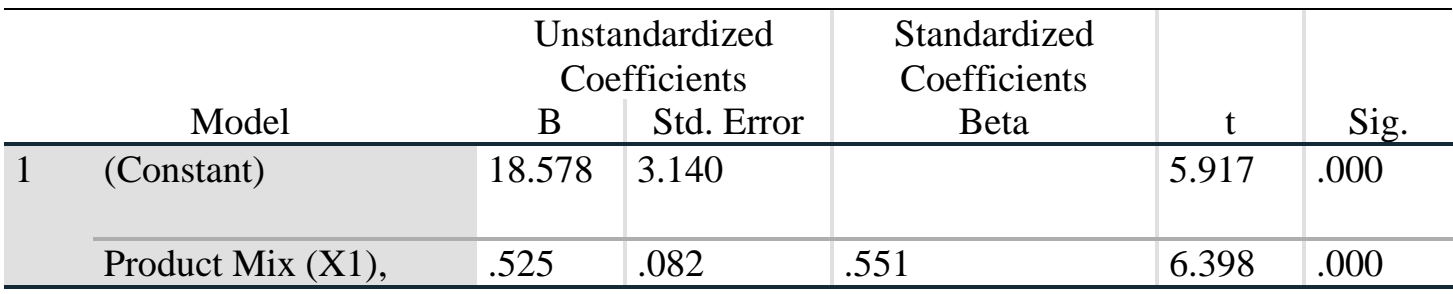

a. Dependent Variable: Purchase Decision (Y)

Based on the test results in the above table, the value of $t_{\text {count }}>t_{\text {table }}$ or $(6.398>1.986)$ is obtained, thus the first hypothesis proposed that there is a significant influence between the product mix on consumer purchasing decisions is accepted.

Table 12.

Hypothesis Test Results Promotional Mix Against Consumer Purchasing Decisions.

\section{Coefficients $^{\mathrm{a}}$}

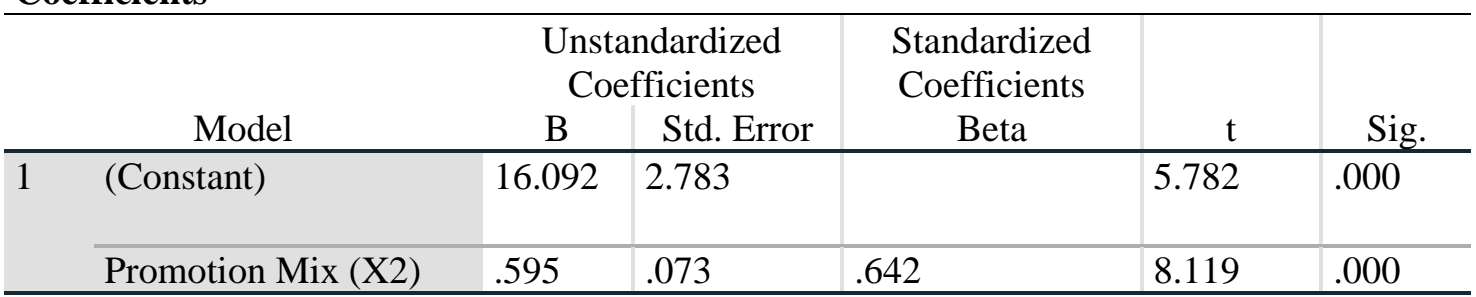

a. Dependent Variable: Purchase Decision (Y)

Based on the test results in the table above, the value of $t_{\text {count }}>t_{\text {table }}$ or $(8.119>1.986)$ is obtained, thus the second hypothesis is proposed that there is a significant influence between the promotion mix on consumer purchasing decisions accepted.

Table 13.

Hypothesis Test Results of Brand Image Against Consumer Purchasing Decisions.

\section{Coefficients $^{\mathrm{a}}$}

\begin{tabular}{|c|c|c|c|c|c|c|}
\hline \multirow{2}{*}{\multicolumn{2}{|c|}{ Model }} & \multicolumn{2}{|c|}{$\begin{array}{l}\text { Unstandardized } \\
\text { Coefficients }\end{array}$} & \multirow{2}{*}{$\begin{array}{c}\text { Standardized } \\
\text { Coefficients } \\
\text { Beta }\end{array}$} & \multirow[b]{2}{*}{$\mathrm{t}$} & \multirow[b]{2}{*}{ Sig } \\
\hline & & B & Std. Error & & & \\
\hline \multirow[t]{2}{*}{1} & (Constant) & 19.379 & 3.289 & & 5.892 & .000 \\
\hline & Brand Image (X3) & .505 & .086 & .517 & 5.862 & .000 \\
\hline
\end{tabular}

a. Dependent Variable: Purchase Decision (Y)

Based on the test results in the table 13, the value of $t_{\text {count }}>t_{\text {table }}$ or $(5.862>1.986)$ is obtained, thus the third hypothesis proposed that there is a significant influence between the brand image on consumer purchasing decisions is accepted.

Hypothesis testing with the F test is used to find out which simultaneous hypotheses are accepted. 
Table 14.

Hypothesis Test Results Product Mix, Promotion Mix and Brand Image Against Consumer Purchasing Decisions.

\begin{tabular}{|c|c|c|c|c|c|c|}
\hline \multicolumn{7}{|c|}{ ANOVA $^{\mathrm{a}}$} \\
\hline & & Sum of Squares & $\mathrm{df}$ & Mean Square & $\mathrm{F}$ & Sig. \\
\hline \multirow{3}{*}{1} & Regression & 595.415 & 3 & 198.472 & 29.832 & $.000^{\mathrm{b}}$ \\
\hline & Residual & 612.074 & 92 & 6.653 & & \\
\hline & Total & 1207.490 & 95 & & & \\
\hline
\end{tabular}

a. Dependent Variable: Purchase Decision (Y)

b. Predictors: (Constant), Brand Image (X3), Product Mix (X1), Promotion Mix (X2)

Based on the test results in the above table, the calculated $F_{\text {value }}>F_{\text {table }}$ or $(29,832>2,470)$, thus the fourth hypothesis proposed that there is a significant influence between product mix, promotional mix and brand image on consumer purchasing decisions accepted.

\section{CONCLUSION}

Based on the results of the study, the product mix has a significant effect on consumer purchasing decisions with a contribution of $30.3 \%$. Hypothesis testing obtained $t_{\text {count }}>t_{\text {table }}$ or (6.398> 1.986). The promotion mix has a significant effect on consumer purchasing decisions with an influence contribution of $41.2 \%$. Hypothesis testing obtained $t_{\text {count }}>t_{\text {table }}$ or (8.119> 1.986). Brand image has a significant effect on consumer purchasing decisions with a contribution of $26.8 \%$. Hypothesis testing obtained $t_{\text {count }}>t_{\text {table }}$ or $(5.862>1.986)$. Product mix, promotion mix, and brand image have a significant effect on consumer purchasing decisions with a contribution of $49.3 \%$ while the remaining $50.7 \%$ is influenced by other factors. Hypothesis testing obtained by the value of $F_{\text {count }}>F_{\text {table }}$ or $(29,832>2,470)$.

\section{REFERENCES}

Adi, P., \& Soepangkat, B. O. (2012). Optimasi Keuntungan Dengan Menggunakan Bauran Produk Di PT. XX. Prosiding Seminar Nasional Manajemen Teknologi XVI.

Al Badi, K. S. (2015). The Dimensions of Marketing Mix. Management and Organizational Studies. https://doi.org/10.5430/mos.v2n1p136

Alma, B. (2011). Pemasaran dan Pemasaran Jasa. In Pemasaran dan Pemasaran Jasa.

Barat, S. (2009). Global Marketing Management. Journal of Global Marketing. https://doi.org/10.1080/08911760903022556

Constantinides, E. (2006). The Marketing Mix Revisited: Towards the 21st Century Marketing. Journal of Marketing Management. https://doi.org/10.1362/026725706776861190

Fristiana, D. A. (2012). Pengaruh Citra Merek dan Harga Terhadap Keputusan Pembelian Pada Ramai Swalayan Peterongan Semarang. Ilmu Administrasi Bisnis.

Habibah, U., \& Sumiati. (2016). The Influence Of Brand Awareness And Brand Image On Purchase Decision (Study On AQUA Consumers in Administrative Science Faculty Brawijaya University Class Of 2013). Jurnal Ekonomi Dan Bisnis.

Hollensen, S. (2010). Marketing management: A relationship approach. Pearson Education. 
Keller, K. L. (2001). Building Customer-Based Brand Equity: A Blueprint for Creating Strong Brands Building Customer-Based Brand Equity: A Blueprint for Creating Strong Brands. Journal of Marketing Communications. https://doi.org/10.1080/13527260902757530

Kilgour, M. (2006). Marketing Management: An Asian Perspective. Australasian Marketing Journal (AMJ). https://doi.org/10.1016/s1441-3582(06)70062-3

Kotler. (2013). Manajemen Pemasaran Jilid 2. In Penerbit Erlangga.

Kotler dan Amstrong. (2008). Prinsip-Prinsip Pemasaran Jilid I. In Erlangga.

Jasmani (2018). Pengaruh Persepsi Merek dan Kualitas Pelayanan Terhadap Kepuasan Pelanggan (Studi Kasus Pada Pt. Bisma Narendra Di Jakarta). Jurnal Mandiri. https://doi.org/10.33753/mandiri.v1i2.18

Mayer, T., Melitz, M. J., \& Ottaviano, G. I. P. (2014). Market size, competition, and the product mix of exporters. American Economic Review, 104(2), 495-536.

Mukherjee, D. (2011). Impact of Celebrity Endorsements on Brand Image. SSRN Electronic Journal. https://doi.org/10.2139/ssrn.1444814

Peter, J. P., \& Olson, J. C. (2014). Perilaku Konsumen dan Strategi Pemasaran. In salemba empat.

Purba, R. (2012). Measuring Consumer Perceptions Through Factor Analysis”. The Asian.

Riaz, W., \& Tanveer, A. (2012). Marketing Mix, Not Branding. Asian Journal of Business and Management Sciences. https://doi.org/10.1108/13612021111112368

Shinta, A. (2011). Manajemen Pemasaran (terjemahan). In Edisi Millenium, Jilid 1.

Sunyoto, D. (2014). Dasar - Dasar Manajemen Pemasaran. In dasar dasar manajemen pemasaran.

Susanti, F. (2015). Pengaruh Bauran Promosi Terhadap Keputusan Klien Dalam Memilih Radio Carano Sebagai Media Promosi Iklan. Jurnal Kbp, 3(1), 104-115.

Swastha, B. (2008). Manajemen Pemasaran Modern. In Liberty, Yogyakarta. https://doi.org/10.1017/CBO9781107415324.004

Tingkir, C. F. (2014). Pengaruh Identitas Merek Terhadap Loyalitas Merek Melalui Citra Merek Dan Kepercayaan Merek Toyota. Jurnal Manajemen Pemasaran. https://doi.org/10.9744/pemasaran.8.2.62-69

Wahyuningsih, W., \& Tanamal, J. (2008). A study on customer satisfaction across information search behavior typology. Gadjah Mada International Journal of Business, 10(1), 25-46.

Wariki, G. M., Mananeke, L., \& Tawas, H. (2015). Pengaruh Bauran Promosi, Persepsi Harga Dan Lokasi Terhadap Keputusan Pembelian Dan Kepuasan Konsumen Pada Perumahan Tamansari Metropolitan Manado. Jurnal EMBA: Jurnal Riset Ekonomi, Manajemen, Bisnis Dan Akuntansi, 3(2).

Zhang, Y. (2015). The Impact of Brand Image on Consumer Behavior: A Literature Review. Open Journal of Business and Management. https://doi.org/10.4236/ojbm.2015.31006 